\author{
K. Rokosz ${ }^{1}$, T. Hryniewicz ${ }^{1}$ K. Pietrzak ${ }^{1}$, W. Malorny ${ }^{2}$ \\ ${ }^{1}$ Koszalin University of Technology, Faculty of Mechanical Engineering, Department of En- \\ gineering and Informatics Systems, Division of Bioengineering and Surface Electrochemistry, \\ Racławicka 15-17, 75-620 Koszalin, Poland \\ ${ }^{2}$ Hochschule Wismar-University of Applied Sciences Technology, Business and Design, \\ Faculty of Engineering, D 23966 Wismar, Germany \\ rokosz@tu.koszalin.pl
}

\title{
SEM AND EDS CHARACTERIZATION OF POROUS COATINGS OBTAINED ON TITANIUMBY PLASMA ELECTROLYTIC OXIDATION IN ELECTROLYTE CONTAINING CONCENTRATED PHOSPHORIC ACID WITH ZINC NITRATE
}

\begin{abstract}
The SEM and EDS results of porous coatings formed on pure titanium by Plasma Electrolytic Oxidation (Micro Arc Oxidation) under DC regime of voltage in the electrolytes containing of $500 \mathrm{~g}$ zinc nitrate $\mathrm{Zn}\left(\mathrm{NO}_{3}\right)_{2} \cdot 6 \mathrm{H}_{2} \mathrm{O}$ in $1000 \mathrm{~mL}$ of concentrated phosphoric acid $\mathrm{H}_{3} \mathrm{PO}_{4}$ at three voltages, i.e. $450 \mathrm{~V}, 550 \mathrm{~V}, 650 \mathrm{~V}$ for 3 minutes, are presented. The PEO coatings with pores, which have different shapes and the diameters, consist mainly of phosphorus, titanium and zinc. The maximum of zinc-to-phosphorus $(\mathrm{Zn} / \mathrm{P})$ ratio was found for treatment at $650 \mathrm{~V}$ and it equals $0.43(\mathrm{wt} \%) \mid 0.20(\mathrm{at} \%)$, while the minimum of that coefficient was recorded for the voltage of $450 \mathrm{~V}$ and equaling $0.26(\mathrm{wt} \%) \mid 0.12(\mathrm{at} \%)$. Performed studies have shown a possible way to form the porous coatings enriched with zinc by Plasma Electrolytic Oxidation in electrolyte containing concentrated phosphoric acid $\mathrm{H}_{3} \mathrm{PO}_{4}$ with zinc nitrate $\mathrm{Zn}\left(\mathrm{NO}_{3}\right)_{2} \cdot 6 \mathrm{H}_{2} \mathrm{O}$.
\end{abstract}

Keywords: Plasma Electrolytic Oxidation PEO, Micro Arc Oxidation MAO, SEM, titanium, porous coatings

\section{INTRODUCTION}

Electrochemical surface treatment of metals and alloys is an important part of surface finishing processes allowing to obtaining required features of nano- and/or micro-layers on selected materials with expected physical, chemical and mechanical properties. The electropolishing (EP) [1-7], magnetoelectropolishing (MEP) [7-29], and high-current density electropolishing (HDEP) [30-32] processes generally result in bright and smooth surfaces with nanometer oxide film created. On the other hand, Plasma Electrolytic Oxidation (PEO), known also as Micro Arc Oxidation (MAO) [33-42], may be used to obtain on metallic substrate the micro-layers, to be employed for different applications, e.g. as a part of automobile catalysts and/or to biomaterials. In case of biomaterials finishing, it is important to create the 
porous surface enriched in antibacterial copper [43-56] or zinc. Zinc enrichment of porous PEO coatings is the main subject of the present paper. In addition, it is also desirable to form the surface with the least amount of vanadium, aluminum, and nickel, which are toxic to the human body [41, 43, 53].

In the present paper, the Authors describe the porous surfaces obtained on titanium after PEO treatment under DC regime of voltage in the electrolyte containing concentrated $(85 \%)$ phosphoric acid $\mathrm{H}_{3} \mathrm{PO}_{4}$ and zinc nitrate $\mathrm{Zn}\left(\mathrm{NO}_{3}\right)_{2} \cdot 6 \mathrm{H}_{2} \mathrm{O}$. A focus was directed on the zinc-tophosphorus $(\mathrm{Zn} / \mathrm{P})$ ratio in the porous coatings obtained.

\section{METHOD AND EXPERIMENTAL SET UP}

Plasma Electrolytic Oxidation (Micro Arc Oxidation) process was used for treatment the samples of CP Titanium Grade 2 with dimensions $10 \mathrm{~mm} \times 10 \mathrm{~mm} \times 2 \mathrm{~mm}$. The plasma electrolytic oxidation (PEO) was performed at the voltages of $450 \mathrm{~V}, 550 \mathrm{~V}$ and $650 \mathrm{~V}$. The electrolyte consisted of a concentrated $85 \%$ analytically pure $\mathrm{H}_{3} \mathrm{PO}_{4}(98 \mathrm{~g} / \mathrm{mole})$ acid, one liter, with $500 \mathrm{~g}$ of zinc nitrate $\mathrm{Zn}\left(\mathrm{NO}_{3}\right)_{2} \cdot 6 \mathrm{H}_{2} \mathrm{O}$ dissolved in it.

The scanning electron microscope Quanta 250 FEI with Low Vacuum and ESEM mode and a field emission cathode as well as the energy dispersive EDS system in a Noran System Six with nitrogen-free silicon drift detector, were used.

A computerized HOMMEL TESTER T800 system of Hommelwerke GmbH to study of surface roughness measurement was used. It was equipped with sliding measuring head Waveline 60 Basic/51808 and the sensor TKL100/17 MO435005. Measuring needle beam was equal to $3.5 \mu \mathrm{m}$ with its angle of $87^{\circ}$. The tracing, evaluation and single measuring lengths, equal to $4.8,4.0$ and $0.8 \mathrm{~mm}$, respectively, were used. Due to the porous surface, the non-contact methods for surface roughness [57] were not possible to be used, inter alia because of the uncertainties in measurement results [58]. According to the EN ISO 4287:1999 [59] and DIN 4768 [60] standards, the following roughness parameters have been measured: arithmetic mean of the sum of roughness profile values ( $\mathrm{Ra})$, mean peak-to-valley height $\left(\mathrm{Rz}^{\mathrm{DIN}}\right)$, ten-point height $\left(\mathrm{Rz}^{\mathrm{ISO}}\right)$, mean-square deviation of the roughness profile $(\mathrm{Rq})$, total height of the roughness profile (Rt), mean width of the roughness profile elements (RSm), the ratio $\left(1_{0}=\mathrm{L} / \mathrm{L}_{0}\right)$ of the developed profile length $(\mathrm{L})$ to the evaluation length $\left(\mathrm{L}_{0}\right)$ and profile peak density $(\mathrm{D})$.

\section{RESULTS}

In Figures 1-3, the SEM images with different zoom lens $(500 \times, 5000 \times, 10000 \times)$ of porous surfaces obtained on titanium after the PEO treatment at $450 \mathrm{~V}$ for 3 minutes, in the electrolyte consisting of $500 \mathrm{~g} \mathrm{Zn}\left(\mathrm{NO}_{3}\right)_{2} \cdot 6 \mathrm{H}_{2} \mathrm{O}$ in $1000 \mathrm{~mL} \mathrm{H}_{3} \mathrm{PO}_{4}$, are displayed. The EDS spectrum related to the SEM image with magnification of 500 times is presented in Figure 4. The recorded peaks of EDS spectrum show clearly that in the studied coating, phosphorus, zinc, titanium, and oxygen were found. It has to be also pointed out that a part of titanium signal may origin also of matrix, not only of the PEO coating. The EDS results of coating formed on Titanium after PEO treatment at $450 \mathrm{~V}$, with using a magnification of 500 times, are presented in Table 1. 


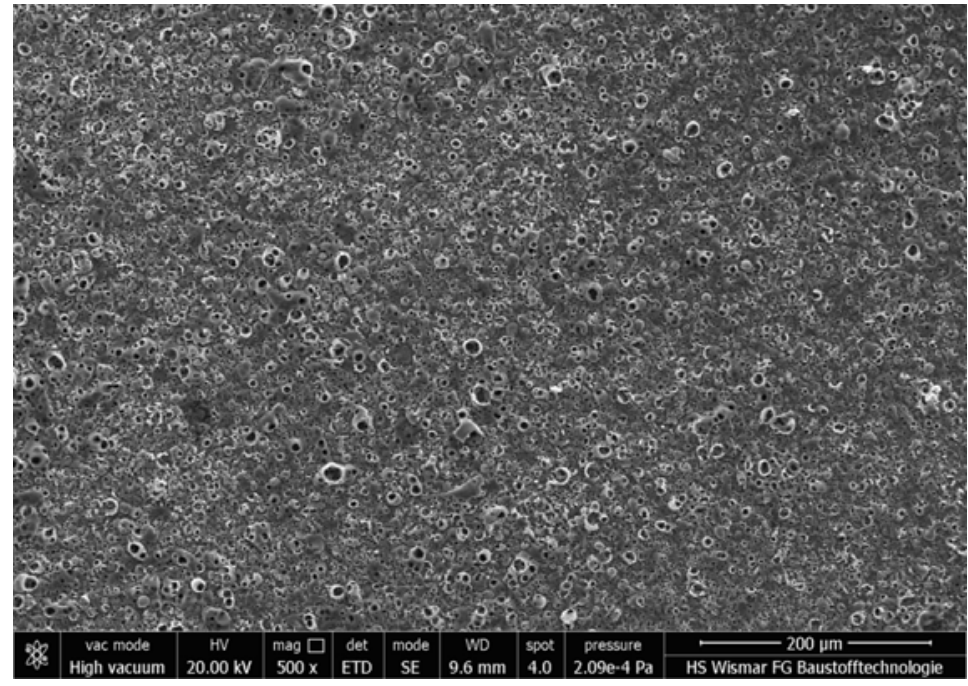

Fig. 1. SEM image of Titanium after PEO treatment at $450 \mathrm{~V}$ for 3 minutes in the electrolyte consisting of $500 \mathrm{~g} \mathrm{Zn}\left(\mathrm{NO}_{3}\right)_{2} \cdot 6 \mathrm{H}_{2} \mathrm{O}$ in $1000 \mathrm{~mL} \mathrm{H}_{3} \mathrm{PO}_{4}$; magnification $500 \times$

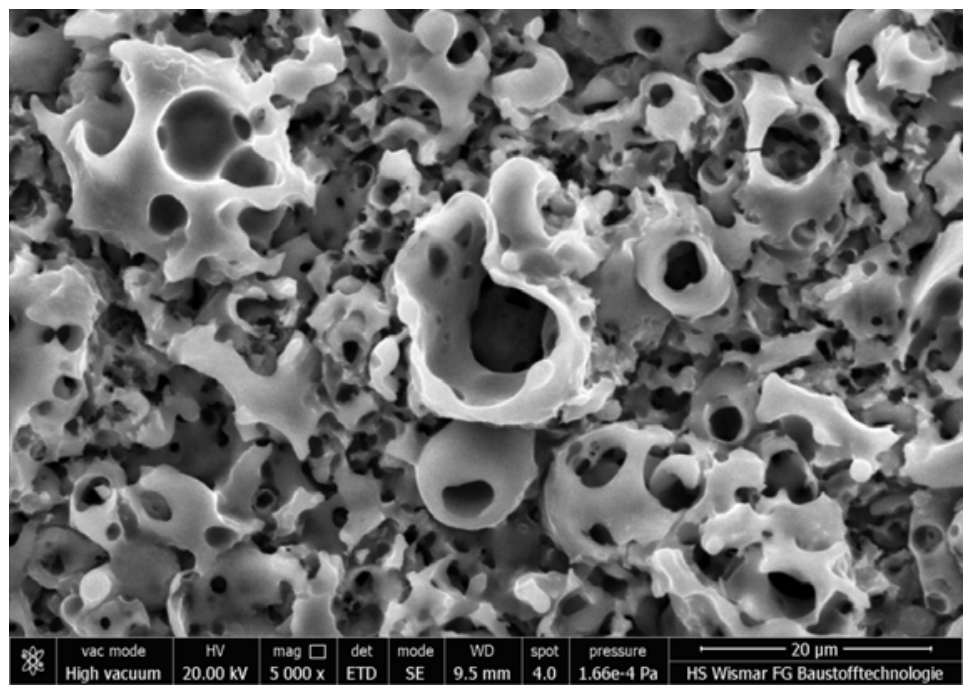

Fig. 2. SEM image of Titanium after PEO treatment at $450 \mathrm{~V}$ for 3 minutes in the electrolyte consisting of $500 \mathrm{~g} \mathrm{Zn}\left(\mathrm{NO}_{3}\right)_{2} \cdot 6 \mathrm{H}_{2} \mathrm{O}$ in $1000 \mathrm{~mL} \mathrm{H}_{3} \mathrm{PO}_{4}$; magnification $5000 \times$

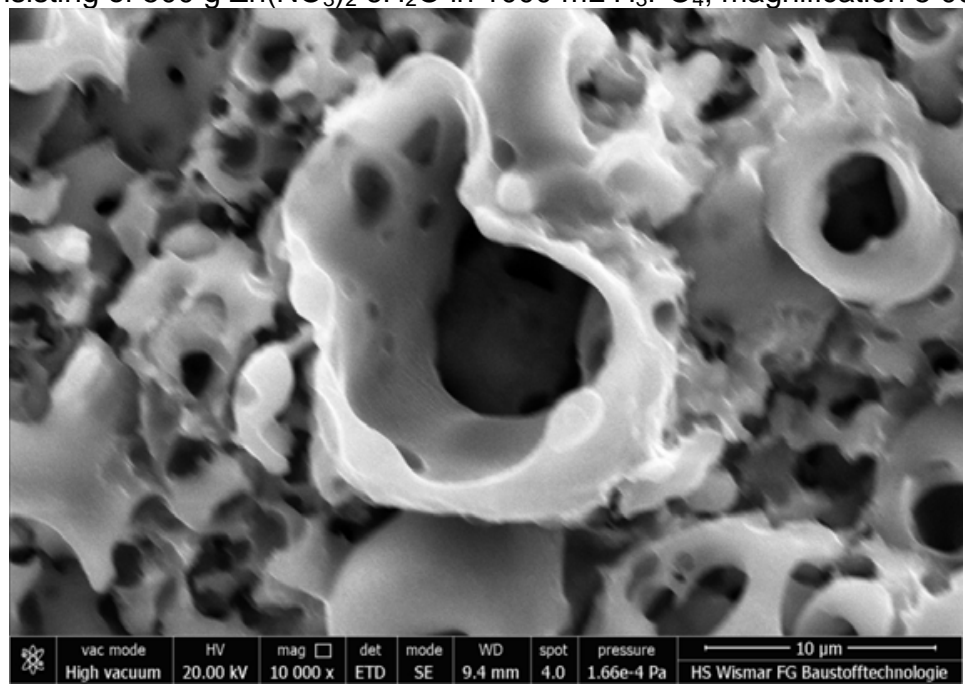

Fig. 3. SEM image of Titanium after PEO treatment at $450 \mathrm{~V}$ for 3 minutes in the electrolyte consisting of $500 \mathrm{~g} \mathrm{Zn}\left(\mathrm{NO}_{3}\right)_{2} \cdot 6 \mathrm{H}_{2} \mathrm{O}$ in $1000 \mathrm{~mL} \mathrm{H}_{3} \mathrm{PO}_{4}$; magnification $10000 \times$ 
The quantification of light element as oxygen by using of EDS method is not possible that way. The analysis of PEO coating chemical composition will be based only on titanium, phosphorus, and zinc, as well as on zinc-to-phosphorus $(\mathrm{Zn} / \mathrm{P})$ ratio, which origin from electrolyte. In porous coating formed during PEO process on titanium at $450 \mathrm{~V}, 53.7 \mathrm{wt} \%$ (45.7 at $\%$ ) of titanium, $9.6 \mathrm{wt} \%$ (6 at $\%)$ of zinc, and $36.7 \mathrm{wt} \%$ (48.3 at $\%)$ of phosphorus, were recorded. In addition, the zinc-to-phosphorus ratio, which is equal to 0.26 and 0.12 , respectively by weight and atomic concentration, is presented.

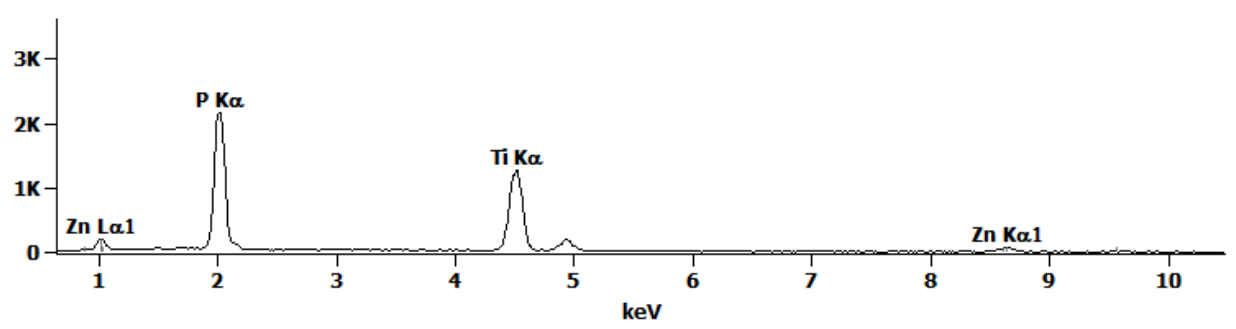

Fig. 4. EDS spectrum of coating formed on $\mathrm{f}$ Titanium after $P E O$ treatment at $450 \mathrm{~V}$ for 3 minutes in the electrolyte consisting of $500 \mathrm{~g} \mathrm{Zn}\left(\mathrm{NO}_{3}\right)_{2} \cdot 6 \mathrm{H}_{2} \mathrm{O}$ in $1000 \mathrm{~mL} \mathrm{H}_{3} \mathrm{PO}_{4}$; magnification $500 \times$

Table 1. EDS results of coating formed on $f$ Titanium after PEO treatment at $450 \mathrm{~V}$ for 3 minutes in the electrolyte consisting of $500 \mathrm{~g} \mathrm{Zn}\left(\mathrm{NO}_{3}\right)_{2} \cdot 6 \mathrm{H}_{2} \mathrm{O}$ in $1000 \mathrm{~mL} \mathrm{H}_{3} \mathrm{PO}_{4}$; magnification $500 \times$

\begin{tabular}{|ccc|}
\hline \multicolumn{3}{|c|}{$\mathbf{4 5 0} \mathbf{V}_{\mathrm{DC}}$} \\
\hline Element & Weight \% & Atom \% \\
\hline $\boldsymbol{P}$ & 36.7 & 48.3 \\
$\mathbf{Z n}$ & 9.6 & 6.0 \\
$\mathbf{T i}$ & 53.7 & 45.7 \\
\hline $\mathbf{Z n} / \boldsymbol{P}$ & 0.26 & 0.12 \\
\hline
\end{tabular}

In Figures 5-7, the SEM images with different zooms $(500 \times, 5000 \times, 10000 \times)$ of porous surfaces obtained on titanium after the PEO treatment at $550 \mathrm{~V}$ for 3 minutes, in the electrolyte consisting of $500 \mathrm{~g} \mathrm{Zn}\left(\mathrm{NO}_{3}\right)_{2} \cdot 6 \mathrm{H}_{2} \mathrm{O}$ in $1000 \mathrm{~mL} \mathrm{H}_{3} \mathrm{PO}_{4}$, are shown.

The recorded peaks of EDS spectrum (Figure 8) show that in the studied coating, phosphorus, zinc, titanium, and oxygen were found. The EDS results of coating formed on Titanium after PEO treatment at $450 \mathrm{~V}$, with using a magnification of 500 times, is given in Table 2. In porous coating formed during PEO process on titanium at $550 \mathrm{~V}, 54 \mathrm{wt} \%$ (46.3 at $\%)$ of titanium, $10.6 \mathrm{wt} \%$ (6.7 at $\%)$ of zinc, and $35.4 \mathrm{wt} \%$ (47 at $\%)$ of phosphorus, were recorded. In addition, the zinc-to-phosphorus ratio, which is equal to 0.30 and 0.14 , respectively by weight and atomic concentration, is provided. 


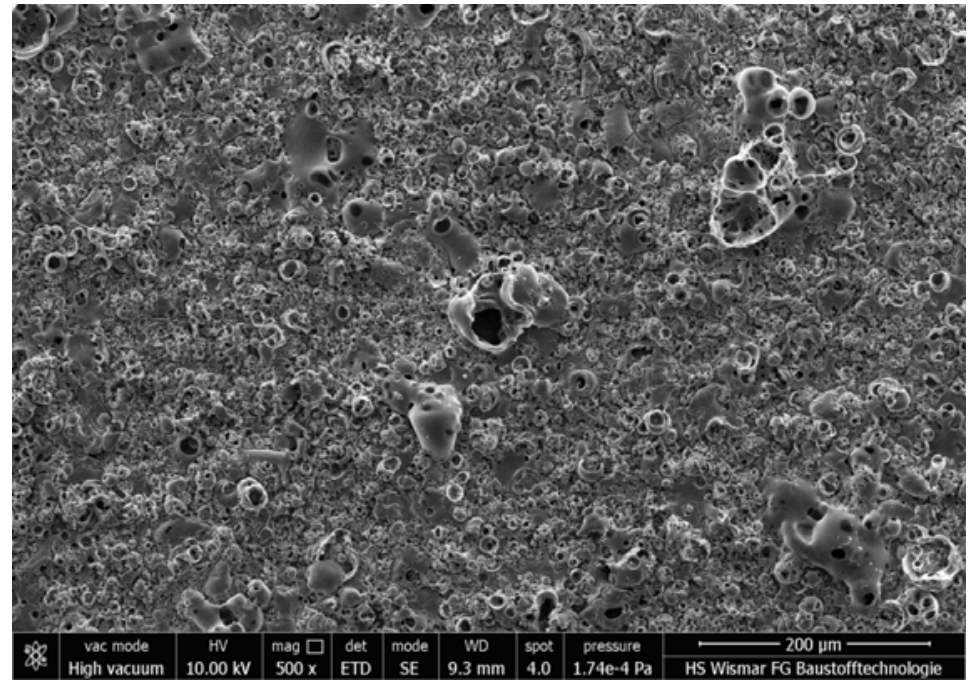

Fig. 5. SEM image of Titanium after PEO treatment at $550 \mathrm{~V}$ for 3 minutes in the electrolyte consisting of $500 \mathrm{~g} \mathrm{Zn}\left(\mathrm{NO}_{3}\right)_{2} \cdot 6 \mathrm{H}_{2} \mathrm{O}$ in $1000 \mathrm{~mL} \mathrm{H}_{3} \mathrm{PO}_{4}$; magnification $500 \times$

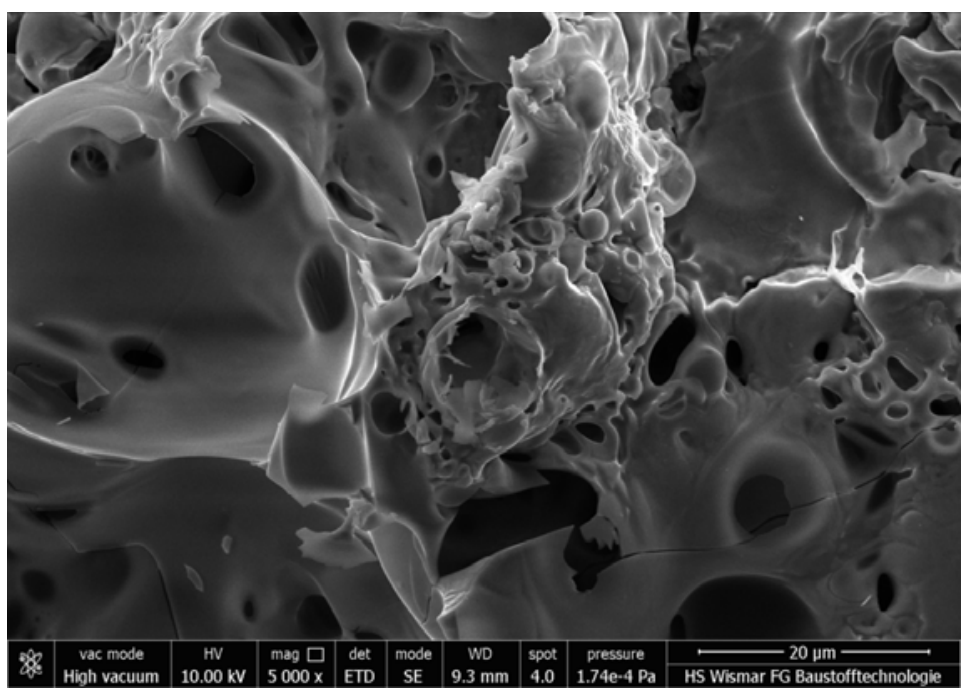

Fig. 6. SEM image of Titanium after PEO treatment at $550 \mathrm{~V}$ for 3 minutes in the electrolyte consisting of $500 \mathrm{~g} \mathrm{Zn}\left(\mathrm{NO}_{3}\right)_{2} \cdot 6 \mathrm{H}_{2} \mathrm{O}$ in $1000 \mathrm{~mL} \mathrm{H}_{3} \mathrm{PO}_{4}$; magnification $5000 \times$

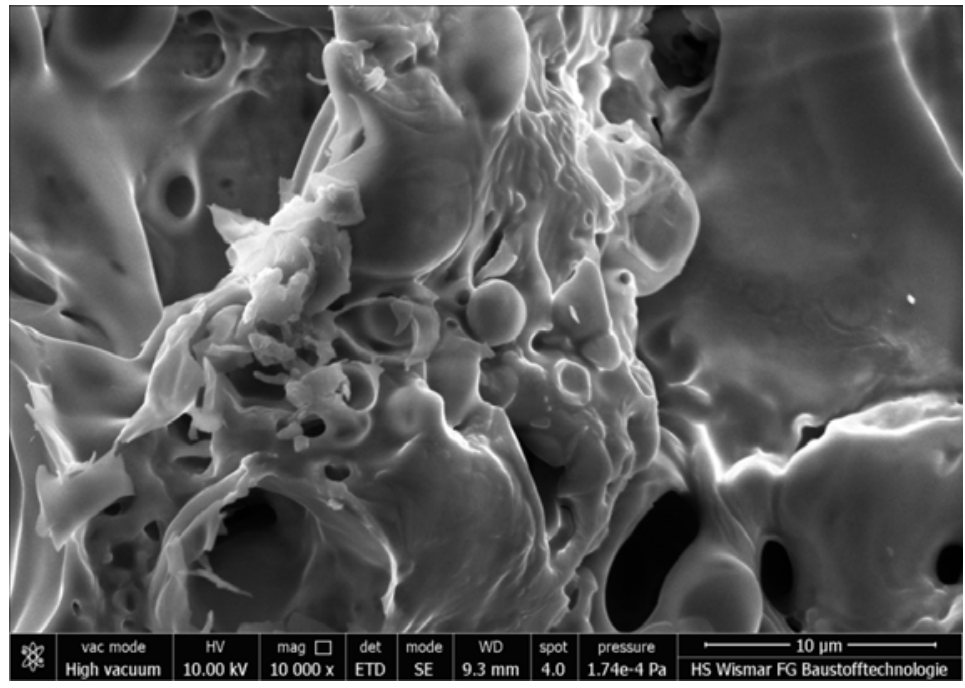

Fig. 7. SEM image of Titanium after PEO treatment at $550 \mathrm{~V}$ for 3 minutes in the electrolyte consisting of $500 \mathrm{~g} \mathrm{Zn}\left(\mathrm{NO}_{3}\right)_{2} \cdot 6 \mathrm{H}_{2} \mathrm{O}$ in $1000 \mathrm{~mL} \mathrm{H}_{3} \mathrm{PO}_{4}$; magnification $10000 \times$ 


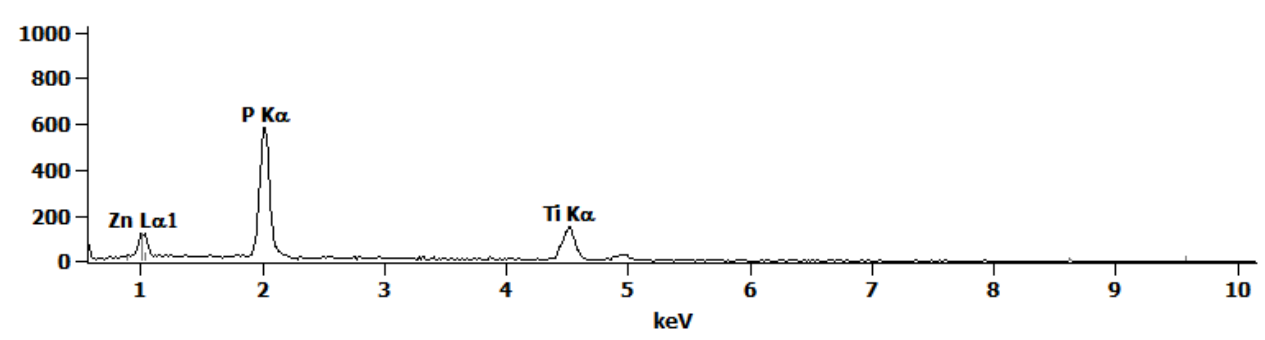

Fig. 8. EDS spectrum of coating formed on $\mathrm{f}$ Titanium after $P E O$ treatment at $550 \mathrm{~V}$ for 3 minutes in the electrolyte consisting of $500 \mathrm{~g} \mathrm{Zn}\left(\mathrm{NO}_{3}\right)_{2} \cdot 6 \mathrm{H}_{2} \mathrm{O}$ in $1000 \mathrm{~mL} \mathrm{H}_{3} \mathrm{PO}_{4}$; magnification $500 \times$

Table 2. EDS results of coating formed on Titanium after PEO treatment at $550 \mathrm{~V}$ for 3 minutes in the electrolyte consisting of $500 \mathrm{~g} \mathrm{Zn}\left(\mathrm{NO}_{3}\right)_{2} \cdot 6 \mathrm{H}_{2} \mathrm{O}$ in $1000 \mathrm{~mL} \mathrm{H}_{3} \mathrm{PO}_{4}$; magnification 500x

\begin{tabular}{|ccc|}
\hline \multicolumn{3}{|c|}{$\mathbf{5 5 0} \mathbf{V}_{\mathbf{D C}}$} \\
\hline Element & Weight \% & Atom \% \\
\hline $\boldsymbol{P}$ & 35.4 & 47.0 \\
$\mathbf{Z n}$ & 10.6 & 6.7 \\
$\mathbf{T i}$ & 54 & 46.3 \\
\hline $\mathbf{Z n} / \boldsymbol{P}$ & 0.30 & 0.14 \\
\hline
\end{tabular}

In Figures 9-11, the SEM images with different zooms $(500 \times, 5000 \times, 10000 \times)$ of porous surfaces obtained on titanium after the PEO treatment at $650 \mathrm{~V}$ for 3 minutes, in the electrolyte consisting of $500 \mathrm{~g} \mathrm{Zn}\left(\mathrm{NO}_{3}\right)_{2} \cdot 6 \mathrm{H}_{2} \mathrm{O}$ in $1000 \mathrm{~mL} \mathrm{H}_{3} \mathrm{PO}_{4}$, are displayed. The recorded peaks of EDS spectrum (Figure 12) show that in the studied coating, phosphorus, zinc, titanium, and oxygen were found. The EDS results of coating formed on Titanium after PEO treatment at $650 \mathrm{~V}$ with using a magnification of 500 times are shown in Table 3 . In porous coating formed during PEO process on titanium at $650 \mathrm{~V}, 52.4 \mathrm{wt} \%$ (45.8 at $\%)$ of titanium, $14.2 \mathrm{wt} \%(9.1 \mathrm{at} \%)$ of zinc and $33.4 \mathrm{wt} \%(45.1 \mathrm{at} \%)$ of phosphorus, were recorded. In addition, the zinc-to-phosphorus ratio, which is equal to 0.43 and 0.20 , respectively by weight and atomic concentration, is given. 


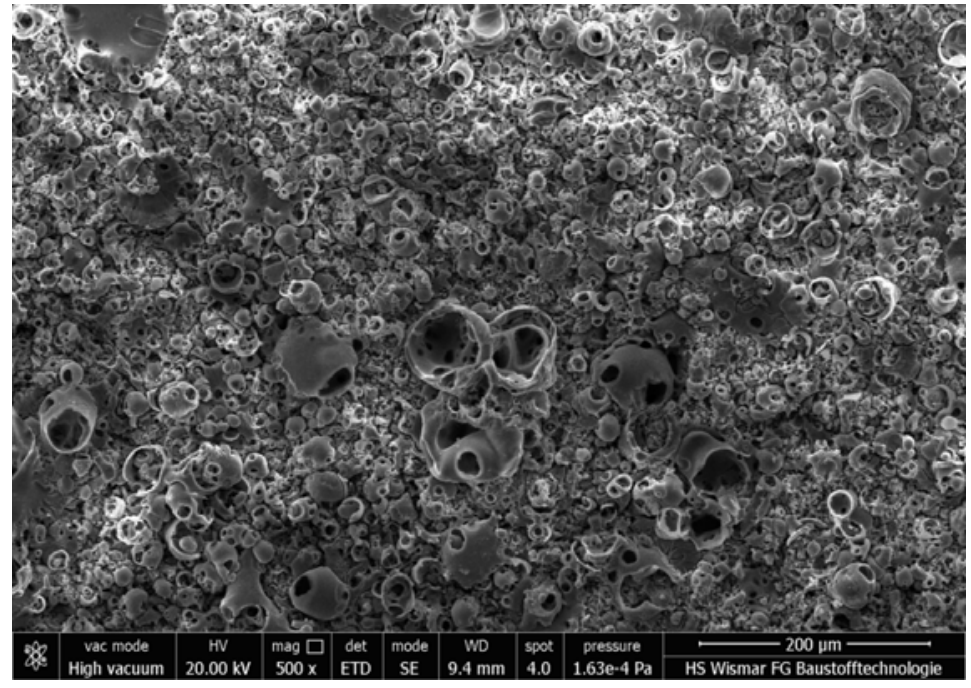

Fig. 9. SEM image of Titanium after PEO treatment at $650 \mathrm{~V}$ for 3 minutes in the electrolyte consisting of $500 \mathrm{~g} \mathrm{Zn}\left(\mathrm{NO}_{3}\right)_{2} \cdot 6 \mathrm{H}_{2} \mathrm{O}$ in $1000 \mathrm{~mL} \mathrm{H}_{3} \mathrm{PO}_{4}$; magnification $500 \times$

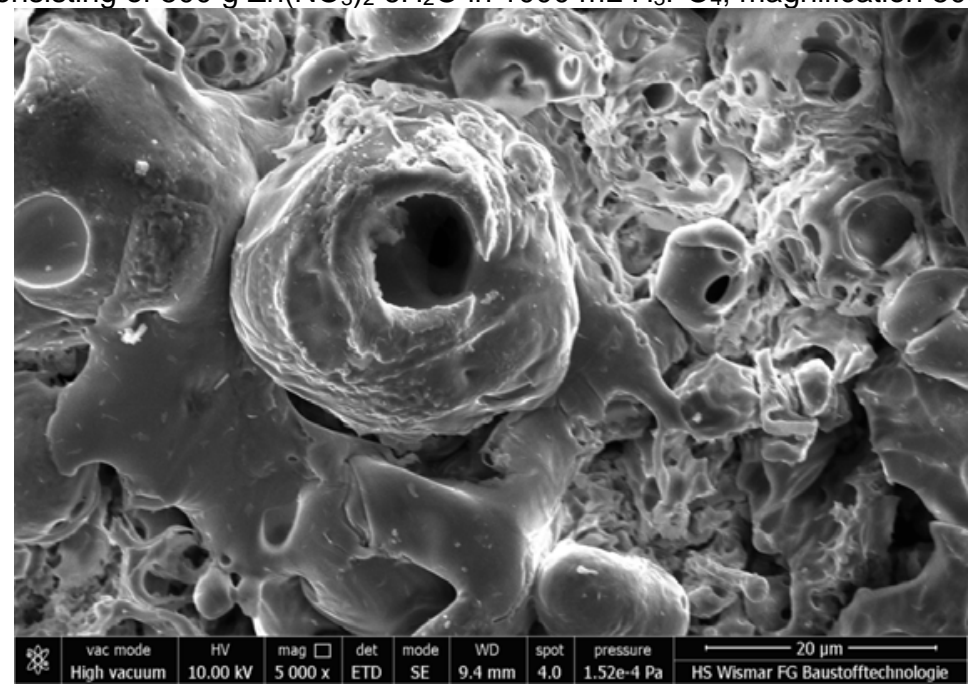

Fig. 10. SEM image of Titanium after $P E O$ treatment at $650 \mathrm{~V}$ for 3 minutes in the electrolyte consisting of $500 \mathrm{~g} \mathrm{Zn}\left(\mathrm{NO}_{3}\right)_{2} \cdot 6 \mathrm{H}_{2} \mathrm{O}$ in $1000 \mathrm{~mL} \mathrm{H}_{3} \mathrm{PO}_{4}$; magnification $5000 \times$

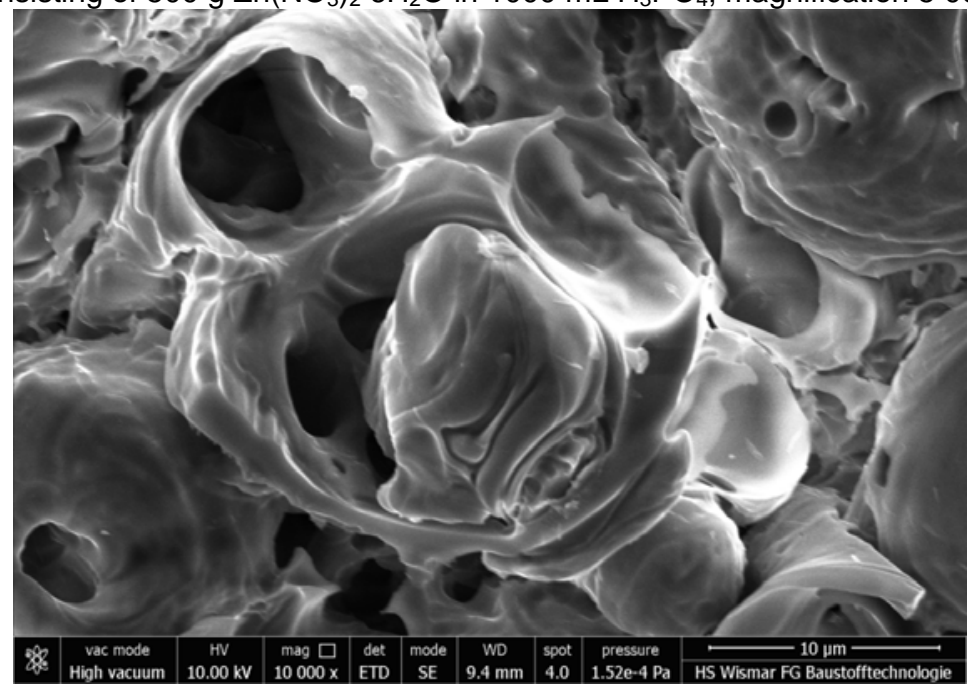

Fig. 11. SEM image of Titanium after $\mathrm{PEO}$ treatment at $650 \mathrm{~V}$ for 3 minutes in the electrolyte consisting of $500 \mathrm{~g} \mathrm{Zn}\left(\mathrm{NO}_{3}\right)_{2} \cdot 6 \mathrm{H}_{2} \mathrm{O}$ in $1000 \mathrm{~mL} \mathrm{H}_{3} \mathrm{PO}_{4}$; magnification $10000 \times$ 


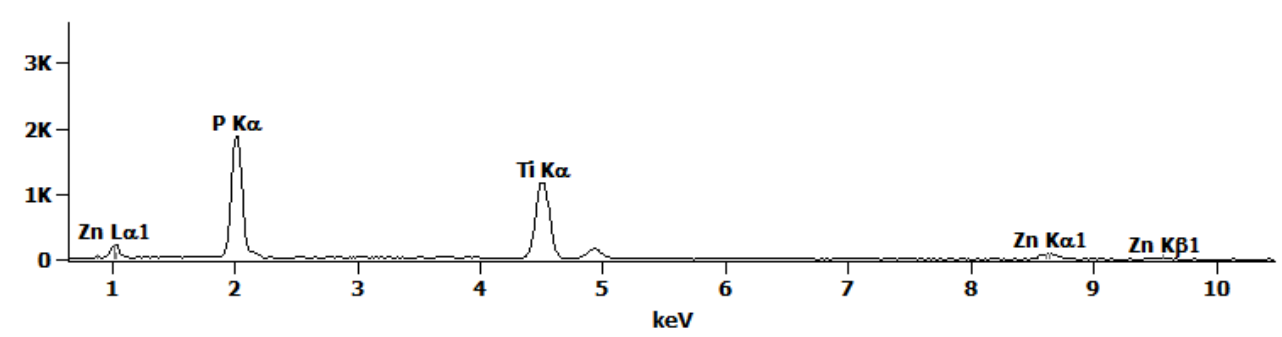

Fig. 12. EDS spectrum of coating formed on $\mathrm{f}$ Titanium after $P E O$ treatment at $650 \mathrm{~V}$ for 3 minutes in the electrolyte consisting of $500 \mathrm{~g} \mathrm{Zn}\left(\mathrm{NO}_{3}\right)_{2} \cdot 6 \mathrm{H}_{2} \mathrm{O}$ in $1000 \mathrm{~mL} \mathrm{H} \mathrm{PO}_{4}$; magnification $500 \times$

Table 3. EDS results of coating formed on $f$ Titanium after $P E O$ treatment at $650 \mathrm{~V}$ for 3 minutes in the electrolyte consisting of $500 \mathrm{~g} \mathrm{Zn}\left(\mathrm{NO}_{3}\right)_{2} \cdot 6 \mathrm{H}_{2} \mathrm{O}$ in $1000 \mathrm{~mL} \mathrm{H}_{3} \mathrm{PO}_{4}$; magnification $500 \times$

\begin{tabular}{|ccc|}
\hline \multicolumn{3}{|c|}{$\mathbf{6 5 0} \mathbf{V}_{\mathrm{DC}}$} \\
\hline Element & Weight \% & Atom \% \\
\hline $\boldsymbol{P}$ & 33.4 & 45.1 \\
$\mathbf{Z n}$ & 14.2 & 9.1 \\
$\mathbf{T i}$ & 52.4 & 45.8 \\
\hline $\mathrm{Zn} / \boldsymbol{P}$ & 0.43 & 0.20 \\
\hline
\end{tabular}

Figure 13 shows the zinc-to-phosphorus ratio for biomaterial such as titanium oxidized in two electrolyte containing concentrated phosphoric acid $\left(\mathrm{H}_{3} \mathrm{PO}_{4}\right)$ with zinc nitrate $\left(\mathrm{Zn}\left(\mathrm{NO}_{3}\right)_{2} \cdot 6 \mathrm{H}_{2} \mathrm{O}\right)$, by PEO treatment. It is clearly visible that the $\mathrm{Zn} / \mathrm{P}$ ratio is increasing over 1.6 times with increasing of PEO voltage from $450 \mathrm{~V}$ to $650 \mathrm{~V}$.

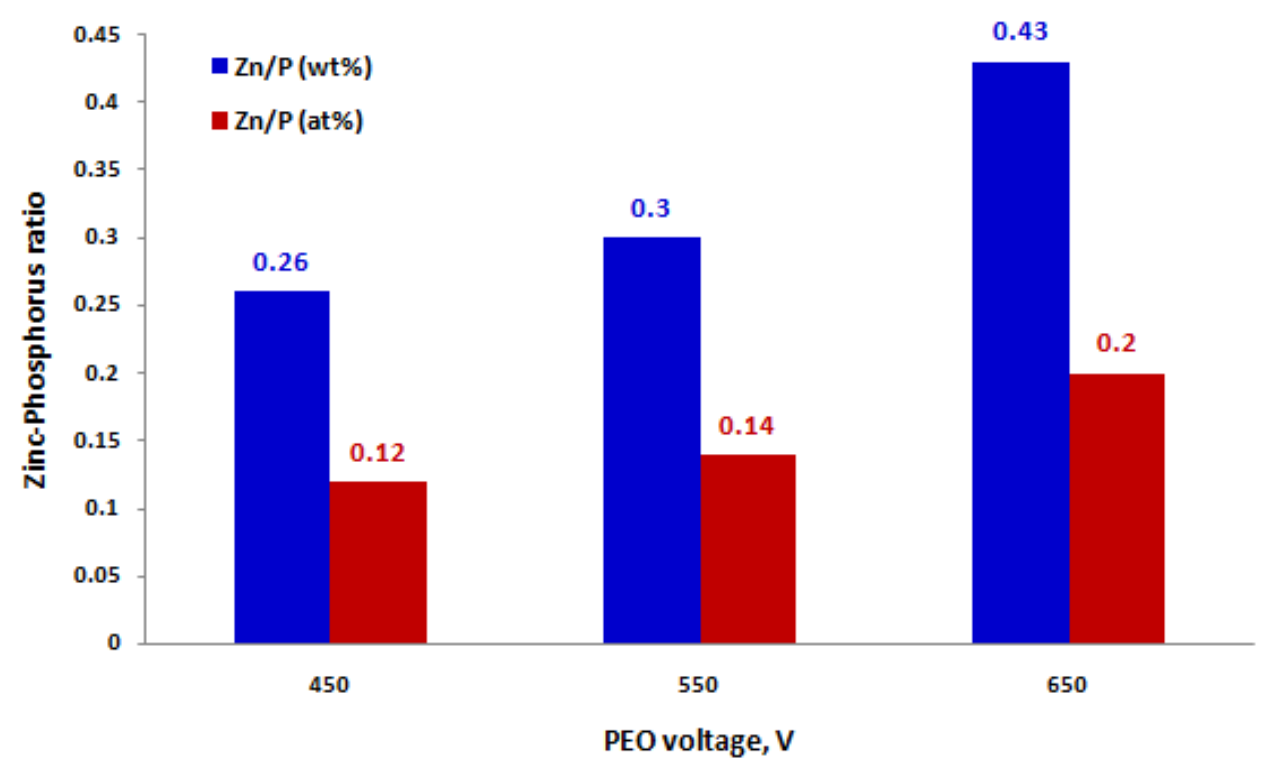

Fig. 13. Zinc-to-phosphorus (Zn/P) ratios based on EDS results (by weight and atomic concentrations) of coating formed on $\mathrm{f}$ Titanium after $\mathrm{PEO}$ treatment at three voltages $(450 \mathrm{~V}, 550 \mathrm{~V}, 650 \mathrm{~V})$ for 3 minutes in the electrolyte consisting of $500 \mathrm{~g} \mathrm{Zn}\left(\mathrm{NO}_{3}\right)_{2} \cdot 6 \mathrm{H}_{2} \mathrm{O}$ in $1000 \mathrm{~mL} \mathrm{H}_{3} \mathrm{PO}_{4}$; magnification $500 \times$ 
In Figure 14, 2D roughness parameters ( $\mathrm{Ra}, \mathrm{Rz}, \mathrm{Rz}{ }^{\mathrm{ISO}}$, Rq, Rt, RSm, $\mathrm{l}_{0}$, D) for PEO surfaces, are presented. For distinguishing of those PEO surfaces obtained with three voltages $(450 \mathrm{~V}, 550 \mathrm{~V}, 650 \mathrm{~V}), \mathrm{Ra}, \mathrm{Rt}$, and $\mathrm{Rz}^{\mathrm{ISO}}$ roughness parameters are the best ones, which may be used to describe the coatings. The biggest roughness was measured in case of the biggest opened pores, whereas the smallest closed pores resulted in low values of roughness measured. For the PEO surfaces obtained at $450 \mathrm{~V}$, the $\mathrm{Ra}, \mathrm{Rt}, \mathrm{Rz}^{\mathrm{ISO}}$ parameters were equal to $3.97 \pm 0.44 \mu \mathrm{m}, 29.74 \pm 1.73 \mu \mathrm{m}, 24.26 \pm 2.08$, while for $650 \mathrm{~V}$ the following values were $2.86 \pm 0.9 \mu \mathrm{m}, 23.78 \pm 2.42 \mu \mathrm{m}, 19.10 \pm 2.03$, respectively.
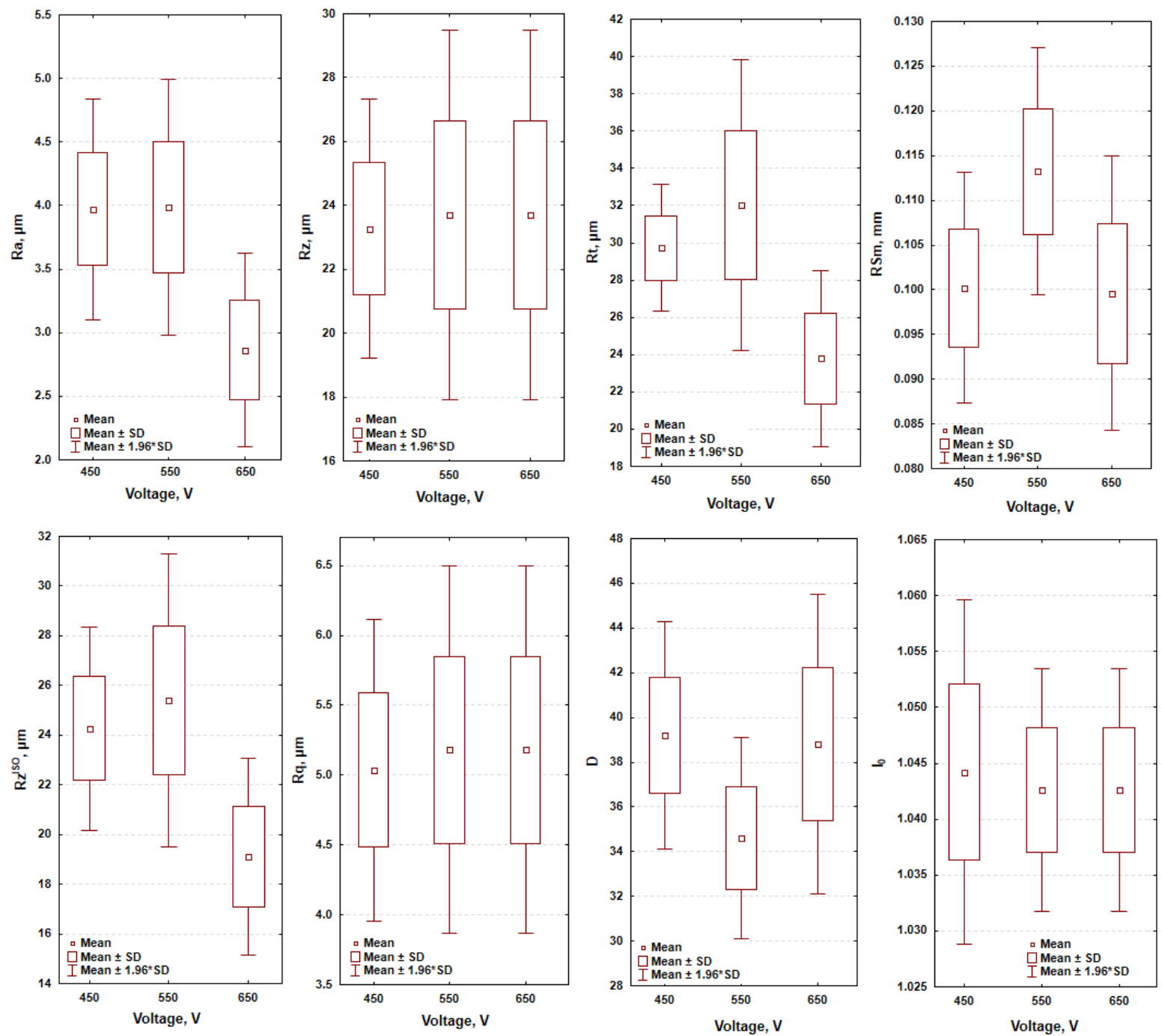

Fig. 14. Roughness parameters of coatings formed on Titanium after $P E O$ treatment at voltages of $450 \mathrm{~V}, 550 \mathrm{~V}$ and $650 \mathrm{~V}$ after $3 \mathrm{~min}$ in $500 \mathrm{~g} / \mathrm{L}$ of $\mathrm{Zn}\left(\mathrm{NO}_{3}\right)_{2} \cdot 6 \mathrm{H}_{2} \mathrm{Oin} 1 \mathrm{~L} \mathrm{H}_{3} \mathrm{PO}_{4}$ electrolyte 


\section{CONCLUSIONS}

In this paper, the results of the porous coatings obtained by PEO treatment on titanium, with using of electrolytes containing of $500 \mathrm{~g}$ zinc nitrate $\mathrm{Zn}\left(\mathrm{NO}_{3}\right)_{2} \cdot 6 \mathrm{H}_{2} \mathrm{O}$ in one liter of concentrated phosphoric acid $\mathrm{H}_{3} \mathrm{PO}_{4}$, are described. The results show that all obtained coatings are porous, however the pore shapes and sizes are different. Recorded data of EDS spectra show that in all the porous coatings obtained, titanium, oxygen, phosphorus, and zinc, are present. In the PEO coatings got at $450 \mathrm{~V}, 53.7 \mathrm{wt} \%$ (45.7 at $\%)$ of titanium, $9.6 \mathrm{wt} \%$ (6 at $\%)$ of zinc and $36.7 \mathrm{wt} \%(48.3 \mathrm{at} \%)$ of phosphorus were found, whereas in those ones formed at $650 \mathrm{~V}: 52.4 \mathrm{wt} \%$ (45.8 at $\%)$ of titanium, $14.2 \mathrm{wt} \%$ (9.1 at $\%)$ of zinc and $33.4 \mathrm{wt} \%(45.1 \mathrm{at} \%)$ of phosphorus, were noted. Additionally, for all coatings, the zinc-to-phosphorus $(\mathrm{Zn} / \mathrm{P})$ ratios were calculated. The maximum of that coefficient was found for the PEO treatment at $650 \mathrm{~V}$ and it equals $0.43(\mathrm{wt} \%) \mid 0.2(\mathrm{at} \%)$, whereas the minimum was recorded for voltage of $450 \mathrm{~V}$ and equaling to $0.26(\mathrm{wt} \%) \mid 0.12($ at $\%)$. However, it has to be pointed out that the presented results will be repeated once more by minimum 5 times in case of statistical data processing and presented in the next papers. From the acquired data it may be concluded that a trend is observed as follows: the higher voltage applied in the PEO treatment, the higher $\mathrm{Zn} / \mathrm{P}$ ratios obtained.

Summing up, it should be noted that presented results confirm a possibility to create enriched in zinc porous coatings by using of Plasma Electrolytic Oxidation process in electrolytes containing concentrated phosphoric acid $\mathrm{H}_{3} \mathrm{PO}_{4}$ with zinc nitrate $\mathrm{Zn}\left(\mathrm{NO}_{3}\right)_{2} \cdot 6 \mathrm{H}_{2} \mathrm{O}$.

\section{ACKNOWLEDGMENTS}

This work was supported by subsidizing by Grant OPUS 11 of National Science Centre, Poland, with registration number 2016/21/B/ST8/01952, titled "Development of models of new porous coatings obtained on titanium by Plasma Electrolytic Oxidation in electrolytes containing phosphoric acid with addition of calcium, magnesium, copper and zinc nitrates". Special acknowledgments are directed to Professor Czesławłukianowicz, DSc PhD, head of Metrology and Quality Division, former Dean at the Faculty of Mechanical Engineering of KUT, for making available a computerized HOMMELTESTER T800 system of Hommelwerke GmbH.

\section{REFERENCES}

1. Hryniewicz T., Physico-chemical and technological foundations of electropolishing of steels (in Polish), 1989, Monograph No. 26, ed. Koszalin University of Technology Publishing, ISSN 0239-7129.

2. Hryniewicz T., Hryniewicz Z. On the solution of equation of diffusion in electropolishing, Journal of the Electrochemical Society,136(12) (1989),3767-3769.

3. Hryniewicz T., Concept of microsmoothing in the electropolishing process, Surface and Coatings Technology, 64(2) (1994), 75-80.

4. Rokicki R., Hryniewicz T., Enhanced oxidation-dissolution theory of electropolishing, Transactions of The Institute of Metal Finishing, 90(4) (2012), 188-196.

5. Hryniewicz T., Rokosz K., ZschommlerSandim HR., SEM/EDX and XPS studies of niobium after electropolishing, Applied Surface Science, 263 (2012), 357-361. 
6. Hryniewicz T., Konarski P., Rokicki R., and Valiček J., SIMS analysis of hydrogen content in near surface layers of AISI 316L SS after electrolytic polishing under different conditions, Surface and Coatings Technology, 205 (2011), 4228-4236.

7. Hryniewicz T., On the surface treatment of metallic biomaterials (in Polish), 2007, Monograph No. 142, ed. Koszalin University of Technology Publishing, ISSN 0239-7129 (155 pages).

8. Rokosz K., Electrochemical polishing in magnetic field (in Polish), 2012, Monograph No. 219, ed. by Koszalin University of Technology Publishing, ISSN 0239-7129, (211 pages).

9. Rokicki R., Hryniewicz T., Rokosz K., Modifying Metallic Implants by Magnetoelectropolishing, Medical Device \& Diagnostic Industry, 30(1) (2008), 102-111.

10. Rokicki R., Hryniewicz T., Nitinol surface finishing by magnetoelectropolishing, Transactions of The Institute of Metal Finishing, 86 (2008), 280-285.

11. Rokicki R., Haider W., Hryniewicz T., Influence of Sodium Hypochlorite Treatment of Electropolished and MagnetoelectropolishedNitinol Surfaces on Adhesion and Proliferation of MC3T3 Preosteoblast Cells, Journal of Materials Science: Materials in Medicine, 23 (2012), 2127-2139.

12. Hryniewicz T., Rokicki R., Rokosz K., Co-Cr alloy corrosion behavior after electropolishing and "magnetoelectropolishing" treatments, Surface and Coatings Technology, 62(17-18) (2008), 3073-3076.

13. Hryniewicz T., Rokosz K., Analysis of XPS results of AISI 316L SS electropolished and magnetoelectropolished at varying conditions, Surface and Coatings Technology, 204(16-17) (2010), 2583-2592.

14. Rokosz K., Hryniewicz T., Raaen S., Cr/Fe ratio by XPS spectra of magnetoelectropolished AISI 316L SS fitted by Gaussian-Lorentzian shape lines, TehnickiVjesnik-Technical Gazette, 21(3) (2014), 533-538.

15. Hryniewicz T., Rokicki R., Rokosz K., Magnetoelectropolishing for metal surface modification. Transactions of The Institute of Metal Finishing, 85(6) (2007), 325-332.

16. Hryniewicz T., Rokicki R., Rokosz K., Corrosion and surface characterization of titanium biomaterial after magnetoelectropolishing, Surface and Coatings Technology, 203(9) (2008), 15081515 .

17. Hryniewicz T., Rokosz K., Polarization characteristics of magnetoelectropolishing stainless steels, Materials Chemistry and Physics, 122(1) (2010), 169-174.

18. Hryniewicz T., Rokicki R., Rokosz K., Chapter 11. Magnetoelectropolished Titanium Biomaterial, in Biomaterial/Book 2, InTech, ISBN 978-953-307-609-6, (2011), 227-248.

19. Hryniewicz T., Konarski P., Rokicki R., Valiček J., SIMS studies of titanium biomaterial hydrogenation after magnetoelectropolishing, Surface and Coatings Technology, 206 (2012), 40274031.

20. Rokosz K. Hryniewicz T., Effect of magnetic field on the pitting corrosion of austenitic steel type AISI 304, OchronaprzedKorozją, 54(7) (2011), 487-491.

21. Rokosz K., Hryniewicz T., Raaen S., Characterization of passive film formed on AISI 316L stainless steel after magnetoelectropolishing in a broad range of polarization parameters, Steel Research International. 83(9) (2012), 910-918.

22. Hryniewicz T., Rokosz K., Investigation of selected surface properties of AISI 316L SS after magnetoelectropolishing, Materials Chemistry and Physics, 123(1) (2010), 47-55.

23. Hryniewicz T., Rokosz K., Rokicki R., Magnetic Fields for Electropolishing Improvement: Materials and Systems. International Letters of Chemistry, Physics and Astronomy, 4 (2014), 98-108. 
24. Hryniewicz T., Rokosz K., Corrosion resistance of magnetoelectropolished AISI 316L SS biomaterial, Anti-Corrosion Methods and Materials, 61(2) (2014), 57-64.

25. Hryniewicz T., Rokosz K., Valiček J., Rokicki R., Effect of magnetoelectropolishing on nanohardness and Young's modulus of titanium biomaterial, Materials Letters, 83 (2012), 69-72.

26. Hryniewicz T., Rokosz K., Rokicki R., Prima F., Nanoindentation and XPS Studies of Titanium TNZ Alloy after Electrochemical Polishing in a Magnetic Field, Materials, 8 (2015), 205-215.

27. Rokosz K., Hryniewicz T., XPS measurements of LDX 2101 duplex steel surface after magnetoelectropolishing, International Journal of Materials Research, 104(12) (2013), 1223-1232.

28. Rokosz K., Hryniewicz T., XPS Analysis of nanolayers obtained on AISI 316L SS after Magnetoelectropolishing, World Scientific News, 37 (2016), 232-248.

29. Rokicki R., Hryniewicz T., Konarski P., Rokosz K., The alternative, novel technology for improvement of surface finish of SRF niobium cavities, World Scientific News, 74 (2017), 152 163.

30. Rokosz K., Hryniewicz T., Simon F., Rzadkiewicz S., Comparative XPS analysis of passive layers composition formed on AISI 304 L SS after standard and high-current density electropolishing, Surface and Interface Analysis, 47(1) (2015), 87-92.

31. Rokosz K., Lahtinen J., Hryniewicz T., Rzadkiewicz S., XPS depth profiling analysis of passive surface layers formed on austenitic AISI 304L and AISI 316L SS after high-current-density electropolishing, Surface and Coatings Technology, 276 (2015), 516-520.

32. Rokosz K., Hryniewicz T., Simon F., Rzadkiewicz S., Comparative XPS analyses of passive layers composition formed on duplex 2205 SS after standard and high-current-density electropolishing, Tehničkivjesnik - Technical Gazette, 23(3) (2016), 731-735.

33. Gnedenkov S.V., Sharkeev Y.P., Sinebryukhov S.L., Khrisanfova O.A., Legostaeva E.V., Zavidnaya A.G., Puz' A.V., Khlusov I.A., Opra D.P., Functional coatings formed on the titanium and magnesium alloys as implant materials by plasma electrolytic oxidation technology: fundamental principles and synthesis conditions, Corrosion Review, 34(1-2) (2016), 65-83.

34. Simka W., Sadowski A., Warczak M., Iwaniak A., Dercz G., Michalska J., Maciej A., Modification of titanium oxide layer by calcium and phosphorus, ElectrochimicaActa, 56(24) (2011), 8962-8968.

35. Han Y., Hong S.H., Xu K.W., Synthesis of nanocrystallinetitania films by micro-arc oxidation, Materials Letters, 56 (2002), 744-747.

36. Han Y., Hong S.H., Xu K.W., Structure and in vitro bioactivity of titania-based films by microarc oxidation, Surface and Coatings Technology, 168 (2003), 249-258.

37. Fei C., Hai Z., Chen C., Yangjian X., Study on the tribological performance of ceramic coatings on titanium alloy surfaces obtained through microarc oxidation, Progress in Organic Coatings, 64 (2009), 264-267.

38. Aliasghari S., Plasma Electrolytic Oxidation of Titanium, PhD Thesis of Faculty of Engineering and Physical Sciences, The University of Manchester School of Materials, (2014), 223 pages.

39. Teh T.H., Berkani A., Mato S., Skeldon P., Thompson G.E., Habazaki H., Shimizu K., Initial stages of plasma electrolytic oxidation of titanium, Corrosion Science, 45 (2003), 2757-2768.

40. Krzakala A., Mlynski J., Dercz G., Michalska J., Maciej A., Nieuzyla L., Simka W, Modification of Ti-6Al-4V alloy surface by EPD-PEO process in $\mathrm{ZrSiO} 4$ suspension, Archives of Metallurgy and Materials, 59(1) (2014), 199-204. 
41. Simka W., Nawrat G., Chlode J., Maciej A., Winiarski A., Szade J., Radwanski K., Gazdowicz J., Electropolishing and anodic passivation of Ti6A17Nb alloy, PrzemysłChemiczny, 90(1) (2011), 84-90.

42. Wang Y., Jiang B., Lei T., Guo L., Dependence of growth features of microarc oxidation coatings of titanium alloy on control modes of alternate pulse, Materials Letters, 58 (2004), 1907-1911.

43. Rokosz K., Hryniewicz T., Raaen S., Development of Plasma Electrolytic Oxidation for improved Ti6A14V biomaterial surface properties, The International Journal of Advanced Manufacturing Technology, 85 (2016), 2425-2437.

44. Rokosz K., Hryniewicz T., Raaen S., Chapon P., Investigation of porous coatings obtained on Ti$\mathrm{Nb}-\mathrm{Zr}-\mathrm{Sn}$ alloy biomaterial by Plasma Electrolytic Oxidation: Characterisation and Modelling, The International Journal of Advanced Manufacturing Technology, 87(9) (2016), 3497-3512.

45. Rokosz K., Hryniewicz T., Raaen S., Chapon P., Development of copper-enriched porous coatings on ternary Ti-Nb-Zr alloy by Plasma Electrolytic Oxidation, The International Journal of Advanced Manufacturing Technology, 89(9) (2017), 2953-2965.

46. Rokosz K., Hryniewicz T., Characteristics of porous and biocompatible coatings obtained on Niobium and Titanium-Niobium-Zirconium (TNZ) alloy by Plasma Electrolytic Oxidation, Mechanik, 12 (2015),15-18.

47. Rokosz K., Hryniewicz T., Dudek Ł., Matysek D., Valiček J., Harničarova M., SEM and EDS Analysis of Surface Layer Formed on Titanium After Plasma Electrolytic Oxidation in $\mathrm{H}_{3} \mathrm{PO}_{4}$ with the Addition of $\mathrm{Cu}\left(\mathrm{NO}_{3}\right)_{2}$, Journal of Nanoscience and Nanotechnology, 16(8) (2016), 78147817.

48. Rokosz K,, Hryniewicz T,, Dalibor M,, Raaen S,, Valiček J,, Dudek $Ł$, Harničarova M., SEM, EDS and XPS Analysis of the Coatings Obtained on Titanium after Plasma Electrolytic Oxidation in Electrolytes Containing Copper Nitrate, Materials, 9(5) (2016), 1-12.

49. Rokosz K., Hryniewicz T., Raaen S., Chapon P., Dudek Ł., GDOES, XPS and SEM with EDS analysis of porous coatings obtained on Titanium after Plasma Electrolytic Oxidation, Surface and Interface Analysis, 49(4) (2016), 303-315.

50. Rokosz K., Hryniewicz T., Chapon P., Dudek Ł., A new approach to porous PEO coating sublayers determination on the basis of GDOES signals, World Scientific News, 57 (2016), 289-299.

51. Rokosz K., Hryniewicz T., Chapon P., Raaen S., ZschommlerSandim H.R., XPS and GDOES characterisation of porous coating enriched with copper and calcium obtained on Tantalum via Plasma Electrolytic Oxidation, Journal of Spectroscopy, Article ID 7093071 (2016) (7 pages); http://dx.doi.org/10.1155/2016/7093071

52. Rokosz K., Hryniewicz T., Malorny W., Characterisation of porous coatings obtained on materials by Plasma Electrolytc Oxidation, Materials Science Forum, 862 (2016), 86-95.

53. Rokosz K., Hryniewicz T., Raaen S., SEM, EDS and XPS analysis of nanostructured coating obtained on NiTi biomaterial alloy by Plasma Electrolytic Oxidation (PEO), TehničkivjesnikTechnical Gazette, 24(1) (2017), 193-198.

54. Rokosz K., Hryniewicz T., Raaen S., Chapon P., Development of copper-enriched porous coatings on ternary $\mathrm{Ti}-\mathrm{Nb}-\mathrm{Zr}$ alloy by Plasma Electrolytic Oxidation, The International Journal of Advanced Manufacturing Technology, 89(9-12) (2017), 2953-2965; DOI 10.1007/s00170-0169206-z

55. Rokosz K., Hryniewicz T., Comparative SEM and EDX analysis of surface coatings created on niobium and titanium alloys after Plasma Electrolytic Oxidation (PEO). TehničkivjesnikTechnical Gazette, 24(2) (2017), 465-472. 
56. Rokosz K., Hryniewicz T., Raaen S., Malorny W., Fabrication and characterisation of porous coatings obtained by plasma electrolytic oxidation, Journal of Mechanical and Energy Engineering, 1(1|41) (2017), 23-30.

57. Kusnerova M., Rokosz K., Kusnerova M., Barcova K., Brazina D., Noncontact method for surface roughness measurement after machining, Measurement Science Review, 12(5) (2012), 184 88; DOI:10.2478/v10048-012-0028-3

58. Kusnerova M, Valiček J., Harničarova M., Hryniewicz T., Rokosz K., Palkova Z., Vaclavik V., Repka M., Bendova M., A proposal for simplifying the method of evaluation of uncertainties in measurement results, Measurement Science Review, 13(1) (2013), 1-6; DOI:10.2478/msr-20130007

59. EN ISO 4287:(1999) Geometrical product specifications (GPS) - surface texture: profile method - terms, definitions and surface texture parameters. International Organization for Standarization.

60. DIN 4768:(1990) Determination of values of surface roughness parameters Ra, Rz, Rmax using electrical contact (stylus) instruments; concepts and measuring conditions. 